Newfoundland and Labrador Studies

\title{
Sheilah Roberts Lukins. Bottoms Up: A History of Alcohol in
} Newfoundland and Labrador

\section{Christopher Reid}

Volume 36, numéro 1, 2021

URI : https://id.erudit.org/iderudit/1082221ar

DOI : https://doi.org/10.7202/1082221ar

Aller au sommaire du numéro

Éditeur(s)

Faculty of Arts, Memorial University

ISSN

1719-1726 (imprimé)

1715-1430 (numérique)

Découvrir la revue

Citer ce compte rendu

Reid, C. (2021). Compte rendu de [Sheilah Roberts Lukins. Bottoms Up: A History of Alcohol in Newfoundland and Labrador]. Newfoundland and

Labrador Studies, 36(1), 150-152. https://doi.org/10.7202/1082221ar d'utilisation que vous pouvez consulter en ligne.

https://apropos.erudit.org/fr/usagers/politique-dutilisation/ 
Sheilah Roberts Lukins. Bottoms Up: A History of Alcohol in Nerwfoundland and Labrador. St. John's: Breakwater Books, 2020. ISBN 978-1-55081-801-7

Alcohol is ingrained into the social construct of Newfoundland and Labrador. From the commercial tradition of "Screeching In" a visitor or newcomer with a shot of liquor to tales of trading Grand Banks fish for Jamaican rum, alcohol maintains a prominent position within Newfoundland culture.

Sheilah Lukins addresses the rich and constant intertwining of alcohol and Newfoundland settler society in Bottoms $U_{p}$, and firmly establishes the long-standing importance of this relationship. As Lukins illustrates, liquor, beer, and ale have been present in Newfoundland dating to at least the beginning of European settlement. Indeed, archaeological and archival evidence relating to the early English permanent settlements at Cupids and Ferryland indicates that colonists constructed breweries to brew alcohol and decrease dependence on imported liquor. As Lukins convincingly argues, liquor's presence in Newfoundland amounted to so much more than just a sociable beverage. In the early days of colonization, settlers used alcohol as medicine and disinfectant, and liquor provided an invaluable source of vitamin $\mathrm{C}$ aboard the sack ships that carried Newfoundland fish to markets in New England, Europe, and the Caribbean. Borrowing from Peter Pope's seminal work Fish into Wine, Lukins outlines the relationship between the Newfoundland salt fish trade and the rise of the Newfoundland merchant class during the seventeenth and eighteenth centuries.

Yet, as settler society developed in Newfoundland, alcohol quickly transitioned from a medicinal and economic necessity to a Newfoundland cultural pillar. Brewhouses established to meet the once-minuscule needs of the colony had increased exponentially in number between the seventeenth and nineteenth centuries. St. John's - often the focus of Lukins's scholarly attention — was seemingly overrun with alcohol consumption; as Lukins states, by the 1830s there was approximately 
one tavern for every 66 St. John's residents. As occurred in Canada and the United States, the prevalence of alcoholism and alcohol-related crimes in Newfoundland gave birth to a grassroots temperance movement in the nineteenth century, whose efforts instigated shortlived prohibition in Newfoundland between 1917 and 1924. Like other nations that implemented alcohol restrictions, Newfoundland society experienced an increase in liquor smuggling and bootleg consumption during the nation's seven-year experiment with prohibition. Later, the post-prohibition period ushered in Newfoundland and Labrador's current system of government regulation of alcohol sales and distribution.

The work itself is divided into two large sections. The first of these - the nine primary chapters - is organized thematically. Chapter One describes the vital role that alcohol played in early settler society, highlighting its use as a medicine and substitute for water on long oceanic voyages. Chapter Two discusses the position that alcohol occupied in Newfoundland's early fish trade and its role in creating a local Newfoundland merchant class. Chapters Three through Seven follow the trajectory of liquor in Newfoundland culture as a social vice, government and social attempts to control or abolish its use, and take the reader through the American prohibition period into Newfoundland's Canadian era. Finally, the book's last two chapters provide a brief history of the various bars and breweries of Newfoundland and Labrador, with particular attention paid to the establishments of St. John's.

The book's second section is a series of appendices of immense value to Newfoundland social historians or those with interest in liquor's role in Newfoundland society. These appendices, of which there are five, provide the reader with a wealth of primary data separate from the work's main text. These appendices detail alcohol-related crimes and court cases in Newfoundland, a registry of seventeenth-century St. John's tavern owners, a registry of nineteenth- and twentiethcentury St. John's liquor-related businesses, and two registries of alcohol-related establishments outside St. John's for the nineteenth 
and twentieth centuries. Lukins's inclusion of these appendices in the published study provides the reader with important context that demonstrates just how prevalent alcohol is, and has been, in Newfoundland and Labrador.

While Bottoms $U_{P}$ is founded on a great deal of research, it would have benefited from greater engagement with some existing literature from an academic perspective. A glance at the various chapter endnotes indicates that much of the work is linked to a wide range of secondary scholarly study, but only readers with a foundation in the history of Newfoundland and Labrador will be able to connect Lukins's argument with the broader historical discussion. However, this lack of engagement with secondary literature is only problematic from an academic perspective; for historical enthusiasts and the general public, this study provides a fascinating overview of alcohol's historical prevalence in Newfoundland and Labrador society.

Perhaps the work's greatest attribute is how it is written. Lukins's casual and easy-to-follow writing style makes the study highly accessible to a broad audience while maintaining a high level of detail expected of an academic study. Given this accessible writing style and the demonstrated amount of research and analysis, Bottoms $U_{p}$ will appeal to both enthusiasts and academics alike.

Christopher Reid Memorial University of Newfoundland 